\title{
Lurching toward Liberalism: Political and Literary Reminiscences
}

\author{
PAUL COREY
}

Have you ever considered how you came by your social, ethical, and political views? Or don't you wonder, or are you afraid to wonder? Is it possible there's a "liberal" or "conservative" gene in the gene pool? I'm sure Dr. B. F. Skinner wouldn't buy that. Liberal, conservative, Republican, Democrat, Socialist, Communist, or anarchist views would just have to be the product of the environment.

I've often wondered where my beliefs came from. In the 1908 presidential campaign, William Howard Taft vs. William Jennings Bryan, I had a "Bryan for President" button and was very proud of it. I was five years old and certainly didn't know what it was all about.

Of course, mine was a Democrat family. But that couldn't have meant much to a kid my age. My father died before I was two, so I couldn't have been aware of his politics. My oldest brother, Olney, voted for the first time in that 1908 election. My oldest sister, Elizabeth, would reach voting age one week after that first Tuesday in November. That didn't mean much to her in 1908. There was talk of women's suffrage at the time but I doubt that it was more than a phrase to me.

My mother could have mentioned politics. But a widow running a 160-acre Iowa farm with the help of three older sons wouldn't have much time to talk politics with her youngest. Besides, on thinking back, I have a feeling that politics and its relation to the Corey family was put away in the closet. I never questioned the wherefore at the time.

Those days were almost a quarter century before radio and 
half a century before TV. On an Iowa farm, a daily paper was always a day late, and we couldn't always afford a daily paper. When we could, it was the Council Bluffs Nonpareil, rather than the Des Moines Register. I think the former had Democratic leanings and the latter Republican. There were local weekly papers:-Marne Free Press (Marne pronounced "Marney"), the Walnut Bureau, and the Harlan Tribune. But they carried little significant political news.

I suppose I heard political talk at meal time, or occasionally when a neighbor dropped in. In farm country, kids hang around to hear adult talk. But women's suffrage and socialism were just words. By the 1912 presidential election, I knew that Eugene V. Debs was a Socialist. A supposed Socialist slogan: "What's mine is yours and what's yours is mine," got changed to, "What's mine is mine and what's yours is mine." That got a laugh from grown-ups.

As a kid, I don't think I understood that joke. And when it came to mail order shopping, something very common on the farm, I remember thinking that Democrats ordered from Montgomery Ward and Republicans from Sears Roebuck.

At the age of nine, I don't believe that women's right to vote meant very much to me. However, I did know that Shelby County, Iowa, had a lady school superintendent. From time to time, she would drop in to visit our local school unannounced. It was a "happening." The superintendent's job was to run the country school system of the county. Rural schools were set on an acre of land two miles apart, with few exceptions, each in the center of a square two miles on a side. This square was called a "school district" and it was administered by a "director."

Traditionally, the director was a farmer willing to look after school business without remuneration. That meant mowing the grass on the school acre, having the school house ready for the incoming teacher in the fall, and hauling coal for the school stove.

Our district was No.9. In 1911 or 1912, no farmer in the district wanted the job. Some didn't have school-age kids; 
some lived at the outer corner of the square and their kids could go to the adjacent district without traveling much farther than they would to go to their legal school. That meant that our school was closed.

Our farm was just across the road north from school Number Nine. Its closure meant that I would have to go two miles, east, north, or west to the nearest school in operation. There wasn't a school two miles south because Indian Creek blocked the road. My mother chose the west school for me. There was talk of tuition but the amount was waived. I rode our pony and staked her out on the school yard during school hours or stabled her in a farmer's barn across the road in bad weather.

Meanwhile, my mother felt that as head of a family and a taxpayer, her son should not be made to travel two miles to school just because no man would take the job as director in our school district. She wrote the county superintendent, talked to neighbors on the telephone party line, and on several Saturdays I hitched Lawn, our safe driving horse, to the single buggy so that she could see farmers in the district, not on our party line, about school business.

Finally my mother was sworn in as director of School District No. 9. She hired a teacher. With the help of my sister Ethel, the schoolhouse was made ready. My brother Rob tidied the school yard and hauled a "short" load of coal to keep the building warm on chilly mornings. And our school opened again for the spring term.

My mother had won the right to do, what until then, had been a man's job in a man's world. That supported the feelings waking up in me that women should have a right to vote.

At about that time I learned something of the economics of work and pay. My brother Rob had taken over the management of the farm. Corn shelling in the fall left a pile of cobs ten feet high and twenty feet in diameter in the middle of the yard. He offered me ten cents to move the cobs into the shelter of the empty corn crib. I worked at the job after school but didn't get it finished. I'll admit to being a lazy kid. But ten cents for many 
hours of labor, even kid labor, wasn't too much incentive. I never finished the job.

My brother piled up the remaining cobs and burned them and refused to pay me for what I had done. I'd been hired to do so much work. I hadn't done it, so I forfeited the pay. Then my mother stepped in and made him pay me for the part I had done-something like eight cents. I wasn't particularly happy about my mother siding with me. It only added to my awareness of being favored as the youngest.

But that wasn't the only time my mother stepped in on a wage situation in my life. I started high school in Atlantic, county seat of Cass County, in the fall of 1917. The U.S. had just entered World War I. My brother Fuller was drafted. Farm prices were rising. In the spring of 1918, mother sold the farm to Rob and bought a house in Atlantic. That summer, I worked for a neighbor of ours in the country for $\$ 30$ a month.

When school resumed that fall, I was a sophomore. Our next-door neighbor in Atlantic got me a job in the jewelry store in which he was a sort of partner. He repaired watches, clocks, and phonographs while maintaining his own optical profession. My job was to open the store at 7:15 a.m., sweep out, wash windows, tend furnace, and do odd jobs until a quarter of nine. After school, I did odd jobs and errands until six o'clock. Saturdays I was at the store from 7:15 a.m. until 10:00 or 11:00 p.m. with an hour off for lunch and dinner. This added up to at least 25 hours a week for which I got $\$ 3.50$ every Saturday night.

I think my mother let our neighbor think that I was mechanically minded. Interest in machines was supposed to be a family tradition. My grandfather, mother's father, invented things. My brother Fuller invented a device to keep the reins from getting under the ends of the doubletree when driving a team of horses hitched to a buggy. All farm boys are supposed to be mechanical, aren't they?

It was that premise that got me the job in the first place. Our neighbor, in order to get more time for his optometrist clientele, started me repairing clocks and phonographs. That meant 
replacing broken springs, lubricating bearings, and making adjustments. It called for no more skill than the ordinary tinkerer with small machines would possess.

But my "promotion" meant that another high school kid was hired to wash windows and sweep out. My pay remained $\$ 3.50$ a week. That might have been all right, except that I was aware of what the store charged for each job. And a couple of jobs brought in more than my weekly wage. As I was expected to do eight or ten jobs a week, it seemed to me that a considerable inequity existed. Of course, the owner had had to hire someone else to do the sweep out and window washing. And for the holiday season he had put on another person to sell and deliver phonographs.

The time I spent working meant that my grades suffered. Mother became concerned. She felt that my earnings didn't make up for my low grades. She wrote the jewelry store owner saying as much, and he let me go the first of the year. I had learned more about employer/employee relations. Then, that spring, like a born-again Christian, it occurred to me that I might aspire to becoming a writer. Looking back, perhaps I should have stuck to phonograph repairing.

This was the first year after World War I, and the farm land boom was on. I worked for my brother on the farm that summer for $\$ 75$ a month. The year before it had been $\$ 30$ a month, remember? And when school started that fall, I got a job in the music store across the street from the jewelry store for $\$ 5$ a week. It was a janitorial job plus repairing phonographs. A much friendlier environment, and my grades didn't suffer. But that wasn't the real reason.

My English teacher made the class write. I wrote poetry, short stories, essays, and (like the other students) read what I wrote to the class. It was wonderfully ego inflating. I read my stuff to my mother, but she thought that the dramatic delivery I had developed made what I wrote sound better than it really was. To her, writing was all right as a hobby, but not as a serious career. Again, looking back, she was undoubtedly right. 
During those years it was inevitable that I absorbed a lot of current ideas about the Russian Revolution. The Bolsheviks were "bad guys." In the 1920 presidential election, the Socialists ran Eugene V. Debs for president. He was in jail, which of course demonstrated what kind of guy he was. But he got upward of a million votes. Cox was the Democratic candidate; Harding, the Republican. The League of Nations was a prime issue.

My mother voted for the first time in 1920; she never told me or anyone I knew how she voted. But she was for the League. That year I was a junior in high school, but I doubt that I had absorbed any more political ideas than the average kid. In a course in economics, our teacher had us give a debate in class entitled Capitalism vs. Socialism.

A classmate, Peter Jantz, and I took socialism. A minister's son, Perry Moore, and Lola Christensen, the brightest student in the class, took capitalism. Peter and I made impassioned speeches summing up the right of workers to a share in management and the distribution of the wealth they produced. The class took a vote and we lost. I think we may have gotten one vote.

I may have acquired some liberal ideas from that experience, but I was still only casually aware that my family's politics were Democrat. Peter came from a Democrat family too, his mother was a strong party member. He and I graduated the following spring, and we entered The University of Iowa in the fall. I majored in journalism, and Pete took pre-law.

Any liberal ideas I might have had began to crystalize at the University but not from subjects I took. In the summer of 1923, I had the chance to ship out with 20 other fellows to the Pacific Lumber Company, in the heart of redwood country, at Scotia, California. It was a company idea to promote redwood lumber in the Middle West. Our rail fare was paid out and back. Going out, we rode in a Pullman. The return trip was made separately by coach as we chose. Some of the party stayed.

I don't remember what we were paid but we agreed to work three months of our summer vacation and our round-trip fare 
was taken out of our pay. We were housed in a company bunkhouse along with 40 or 50 other workers, and a room charge was taken out of our pay. We ate in a large mess hall, and the price of each meal was deducted from our checks. I had taken $\$ 50$ with me, my total savings at the time. I returned with $\$ 50$ but no more.

That was my first experience working for a big corporation. Also the first time I had been so far from home alone. On the farm, I had met a few "drifter" types. But in the lumber mill, I met real "working stiffs." There were political refugees from Central America-Guatemalan revolutionaries. There was an honest-to-God member of the International Workers organization, a "Wobbly." He told me quite casually what they stood for. It didn't sound nearly as bad as the impression I'd been given. He really seemed quite an ordinary guy, not a bewhiskered, bomb-throwing Bolshevik.

In August, President Harding died in the Palace Hotel in San Francisco. I hadn't been too happy when he won the election in 1920. News later of the Teapot Dome Scandal seemed like what was to be expected from a Republican administration.

News of the president's death reached Scotia with the San Francisco Chronicle on the evening train. One of the guys in our group came around reporting the story. It was after nine o'clock, and I was already in bed. He announced that "President Harding died in San Francisco." Later he said I mumbled, "Good thing. Probably saved the Republican Party." He was a bit indignant at my reply, but he was a good Democrat and explained "that I was too sleepy to know what I was saying."

I don't know that those were my exact words. At that time, I had little respect for the GOP or the administration. In addition to political scandals, the agricultural economy was scraping bottom. The previous summer, I had worked on the farm for $\$ 30$ a month again.

That fall (1923) I returned to the University and my job in the Geology Library. It was a good job. I could do most of my studying while serving the students using the library. My mother had moved to lowa City where we had an apartment. 
Charles Nelson roomed with me. We had been in Atlantic High School together, and he was also interested in writing. I got him a job as my assistant in the library.

I took a journalism course in reporting and did assignments for The Daily Iowan. My instructor was Professor William Shipman Maulsby-Major Maulsby we called him. I might have known how he came by the "Major" but I've forgotten. But I haven't forgotten the influence he had on me.

Sometimes he acted like a harassed instructor trying to save his "starving family" and his students were letting him down. Other times he became a hardboiled copy editor and could rip a student's news story apart in a way that could curdle a neophyte's blood. Some of the students took him seriously and didn't like him. But I felt that his weird way of teaching toughened my thinking, made me a skeptical observer, and nurtured my youthful cynicism.

At that time, I was probably more interested in the opposite sex than in politics. President Coolidge, moving up from vice-president, had done nothing to improve my opinion of Republicans, or politicians. I started writing some free verse under a pseudonym, which the editor of The Daily Iowan published in his special column. One of the first got me an undeserved reputation on a part of the campus I really knew nothing about. Briefly, that poem was about a student who died, his girlfriend went to his funeral, and that night she dated another guy.

Quite unknown to me, a fraternity student had died. There had been a funeral. I don't know if he had a girlfriend who stepped out the night after or not. But a delegation from the fraternity descended upon the editor and wanted to know who wrote that poem. The editor had a tough time shielding me. All I had done was make a cynical statement about women. I was in the throes of recovering from a girl back in Walnut, lowa, who had "dumped" me while I was in the lumber mill. Anyhow, it got me known on campus even if I wasn't aware of the status.

In my junior year, I took advanced ROTC. The government 
paid me $\$ 10$ a month, as I recall, and gave me a uniform. I needed any help I could get. The following summer, I went to camp at Fort Snelling. It might have paid a bit more for those six weeks, but I figured that the only other job opening would be back on the farm. After a summer in a lumber mill, working on the farm would be plain dull.

I got a lot more extracurricular education that year. Paved roads were scarce in the Middle West at that time. And hitchhiking had become a new way of getting from here to there. Thumbing rides was the way I got to the Twin Cities area. The Volstead Act-prohibition-had become a law to be broken. I'd learned a little about that in the lumber mill. I learned more in Minneapolis. And I reached voting age.

In August 1924, after my return to the University from Fort Snelling, the University Library hired me and Charles Nelson to move the books of the branch Geology Library to a larger room in the same building. Having run that library for two years, we were thoroughly familiar with the books and how they should be shelved. But moving them and reshelving them was a dull sort of job. Come to think of it, I had never had a job that wasn't dull. Dullness and the lack of incentive is a great teacher of "goldbricking." Actually the incentive was to make the job last as long as we could, which we did. By that time I had a very low opinion of jobs, of economics, and of politics.

The Geology Library change was a part of overall University expansion at that time. The Daily Iowan became a complete newspaper with its own publishing facility in Close Hall, one of the older buildings on campus. The printing press and the linotypes occupied the half-basement floor with offices and classrooms fronting to the east and south. The floor just above the press had been removed leaving a balcony or mezzanine floor for editorial offices. Only the top floor, which was occupied by the three campus literary societies, remained unchanged.

The Iowan offices were a natural hangout for journalism students and stringers for state and national papers connected with the school. That fall many political arguments took place 
there. By this time, women's suffrage was pretty much accepted, and there was a strong feminist movement at the University.

I had no problem there. Equal rights for women fitted my past-the time my mother became director of School District No. 9. But the politicking that September didn't grab me. I was aware that Coolidge was running on the Republican ticket and an unknown named Davis on the Democratic. And Robert M. La Follette had come out as a third-party candidate-Progressive. Not much to excite a first-time voter.

At that time, Professor "Major" Maulsby had a graduate assistant named Ted Gallup. Later he became known as George W. Gallup, the pollster. But I only knew him as Ted. He was serious and hard-working, and an ideal counterweight to the Major. I think that I considered myself a radical, an iconoclast, a sophisticate. Those were words of the 1920s. Today I suppose I'd have been called a weirdo or a flake. I had no idea what Ted Gallup thought of me.

The semester had barely started when a young man came to the apartment where my mother and I and Charles Nelson lived. He said he had stopped at The Daily Iowan office and that Ted Gallup suggested he look me up. He was after someone to work for La Follette on the campus. My job would be to organize a La Follette Club among the students.

So far I had never really considered politics. I had amused myself with organizing. After my freshman year, I had returned to the farm and organized a "literary" society among friends in Clay Township. The previous spring, I had written the bylaws for a fraternity some fellows I knew wanted to form. With such scant experience, I undertook to organize a $\mathrm{La}$ Follette for President Club.

I suppose I knew as many of the radicals on campus as anyone. An unofficial group, calling itself the Pelican Club, met for dinner once or twice a month at an inn on the edge of the campus. The name came from the limerick:

A wonderful bird is the pelican,

His beak can hold more than his belly can. 
He can hold enough in his beak

To last him a week,

But I don't see how in helican.

This group met to discuss and argue subjects of social interest. The feminist revolt of the twenties was a hot topic. University women were shocking the world by bobbing their hair, rejecting corsets and lace and button shoes that came almost to the knees, and smoking cigarettes. "Free love" and "trial marriage" could take up an evening. All of which probably doesn't mean much to the Ms. of today, but a woman who wrote an editorial for the Iowan asserting that a woman's role in life was more than producing babies was called "degenerate" by the director of the School of Journalism.

There were other issues. The senator from Iowa up for re-election was Smith W. Brookhart. The collapse of the farm land boom following the war years had ruined many farmers. Many who hadn't resorted to making "hooch" in their cornfields to beat the Volstead Act were losing their land. Brookhart appealed to them for support. But he had made a trip to the Soviet Union and came back saying that it wasn't as terrible a place as it was painted. That was as great a mistake to make in those days as it is today. He lost the election.

The La Follette Club supplied speakers to present La Follette's programs for farmer and labor meetings. We got stories in the newspapers. I don't remember that we did anything spectacular. I wasn't a good PR person. But all of it brought me in touch with the issues and made me conscious of the shallow campaigns run by Coolidge and Davis. Facts still show La Follette getting about 4,823,000 votes nationally, the most ever received by a third-party candidate. But Coolidge won.

I voted with pride that year, but the results of the 1924 election left me with a very sour opinion of the American electorate. I vowed never to vote again. And didn't for 12 years.

One of the people I met in the School of Journalism was a ranch-lean and weathered guy from Colorado. He was a free-lance reporter studying journalism, several years older than I, but a loner, pretty much like me. We had both been in 
the Major's journalism class the previous year. His name was E.K. Edwards, and we got better acquainted that second year. He told me that before he came to The University of Iowa he had taken a job in the Rockefeller coal mines in Colorado. This was at the time of the famous Ludlow Massacre. Strikers were starved and even murdered. E.K. hadn't known what he was getting into when he hired on as a strikebreaker. He was just a kid. The first day he was escorted into the mine by a big guy walking in front of him and a big guy walking behind. Each wore revolvers strapped to both hips. The next day he didn't go back. That was more labor history to come my way. It reinforced my kneejerk sympathy for the underdog.

That fall the Ku Klux Klan held a promotion meeting at the inn near the campus where students ate regularly and meetings and dances were held. The faculty especially was invited to come. Photojournalism was one of E.K.'s interests, but night pictures weren't easy to get. Those were days before flash bulbs. Flash powder in a trough device, held on the end of a stick, was ignited just as the photographer snapped the camera. E.K. asked me to handle the flash. We were to wait until the KKK meeting broke up and take a picture of the people who came out.

He and I waited across the street from the inn. Several other people were present. At about ten o'clock the door of the inn opened, and people came out on the porch. I was ready with the flash powder. The crowd on the porch grew. E.K. said "Now!" and I lit the flash. In the sudden glare, I heard the camera click. Then we were running hell-bent down the alley behind the Law Building. We came out of the next street over and hurried on to the Journalism Building.

One of the innovations at the Iowan was a darkroom. It was used by staff photographers and stringers. E.K. headed for it immediately to develop his film. I hung around upstairs at the city desk. Suddenly, ten or a dozen professors burst in and headed for the editor's office. Who took that picture?

The editor knew nothing about it. It had not been an Iowan assignment. E.K. had hoped to sell the shot and story to the 
Des Moines Register-maybe the Chicago Tribune. But we, it seems, had shot the wrong crowd. We got those rejecting the Klan pitch and were walking out.

By this time E.K. had developed his film and came up with a wet print. I can still see that picture. One of the profs on the porch was just putting on his hat, his wavy silvery hair conspicuous in the flash. E.K. had no intention of smearing innocent people. But these professors had accepted the invitation of the Klan. Even those who walked out on the Klan were newsworthy. But the profs demanded that E.K. give up the film and the print. There was a question of censorship and First Amendment rights. Finally, E.K. gave in; his first successful try at night photojournalism had been shot down.

E.K. was definitely an underdog. Other journalism students hanging around the Iowan office tried to get him to reveal what his initials stood for. He'd never say. But after we'd been friends for awhile, he did admit to me that the E. stood for "Ether." Ether K. Edwards. But he'd never say what the K. stood for. I always maintained that the K. was for Kerosene: Ether Kerosene Edwards. He was afraid of women. He'd do almost anything to avoid any contact with the opposite sex. But for a guy with given names he obviously couldn't be proud of and a spectacular timidity, to stubbornly pursue a career like journalism, I think must have done something to sustain my determination to become a writer.

The last semester at the University I took a two-hour course, the title of which I can't recall, but it dealt with a social history of the United States. One of the many facets of American life that caught the "tired, poor, huddled masses" when they reached these shores was called the Padrone system. It might have been an early infiltration by the Mafia. When immigrant families ran into difficulties with the illusive American dream, they were forced to allow their children to be exploited by unscrupulous individuals called Padrones.

When I was 11, my mother and I visited her family in Illinois and Indiana. We took a local train from Marne to Atlantic and a flyer to Chicago. From the La Salle Street Station, we had to 
go to the Dearborn Street Station to get a train to Momence, my mother's hometown. The distance wasn't more than three blocks. We could hire a hack. Or we could walk. But we had heavy bags.

Hanging around the Rock Island Station were several roughlooking teenage boys, offering "Carry your bags, mum." My mother decided we'd walk, and hired one of these youths to tote our luggage. A swarthy kid, three or four years older than me, grabbed our bags and set off at a trot. I kept up with him. We outdistanced my mother. At the corner of Dearborn, we turned south. Those bags were heavy, and the young carrier was having trouble. This was September and hot in Chicago. He stopped at the next corner to wipe his forehead. I looked back. My mother was coming as fast as she could along the crowded sidewalk.

Believe me, as an eleven-year-old country kid, I was scared. The moment we paused, a swarthy man seemed to materialize from the crowd. I wouldn't have known how old he was at my age. He and our young carrier exchanged angry words. Finally the boy took a handful of change from his pocket and gave it to the man, who walked quickly away. By that time my mother had caught up with us. The carrier immediately grabbed up our bags and started off at a trot, with me keeping beside him. We reached the Dearborn Street Station, and he set down our bags.

While we waited for my mother to catch up and pay him, he told me that I was a good runner; that some of the boys who carried bags ran off with them. But, he said, he never did such a thing. Thinking about that when I took that course, I realized that thanks to our heavy luggage and my country-boy speed the carrier had been kept from running off with our bags. Ten years later it dawned on me that I had been in a little part of the seamier side of the American dream for immigrants. It was an enlightening memory.

In June of 1925, I got my B.A. in journalism, and started the first of two jobs in Chicago, in Kroch's Bookstore on Michigan Avenue. The shop had a mezzanine floor, and Mr. Kroch's desk pressed against a railing where it overlooked the most 
active part of the store. From time to time during the day, $\mathrm{Mr}$. Kroch would yell, "Miss Bittner!" She was his secretary. He could be heard from one end of the store to the other. I often wondered what customers thought about Mr. Kroch bellowing like Captain Bligh on his quarter-deck.

I was never sure what my job was other than to familiarize myself with the stock, which I did fairly quickly. One day, he caught me waiting on a customer. Apparently I wasn't supposed to be doing that yet. Later, one of the clerks said that he had referred to me as "that Bolshevik," and he fired me at the end of three weeks.

My next job was as a reporter for a real estate magazine. It was dull work but the people on the staff were fun to work with. When I gave notice of quitting early in 1926, I was offered a raise to stay. But I was still determined to become a writer and planned to go to New York.

Before going, I returned to Iowa City to renew old acquaintances and make new ones, and finish up a novel manuscript. I visited my former roommate, Charles Nelson, who was completing his last year at the University. I met Ruth Lechlitner who was working for Professor John T. Frederick and The Midland, while doing graduate work toward her M.A. I was very impressed with her poetry and with her. However, New York was my immediate destination, and I set out with another friend from Pelican Club days in late March.

In 1926, New York City was a great place. We got off the train at Pennsylvania Station, took the Seventh Avenue Subway down to Fourteenth Street, got off at Sheridan Square in Greenwich Village, and found ourselves on Bank Street. We had followed the directions given us by two women friends from the University who had gone to New York the previous summer and were living at 11 Bank Street.

They hadn't gone to work yet. They gave us breakfast, then took off to their jobs. A room was available at 13 Bank, we took it and moved in. We were established before noon and very impressed by the city. By comparison with Chicago, the streets here were wonderfully clean and neat. In those days a person 
could walk the streets safely day or night, with perhaps the exception of Hell's Kitchen at night. It was a beautiful spring day. Our prospects seemed very bright.

My first job was investigating applicants for insurance. I was given a week's training and sent out the following Monday. The company got $\$ 1$ from the insurance companies for each investigator's report. The investigators were expected to interview from four to six or more people who knew each applicant being investigated.

I was paid $\$ 28$ a week. It dawned on me fairly soon that any thorough investigation could not be made of the load of applicants each investigator was given to cover. At \$1 each, fifteen or twenty applicants had to be investigated every day by each investigator for the company to pay the investigator's salary and make a profit. That would mean 100 or more interviews a day. I couldn't possibly do that honestly. I found that the regulars working for the company wrote their reports in speakeasies or at home, falsifying interviews. So I made an ethical judgment and quit. Today, I would probably be accused of an attitude problem.

My determination to be a writer could very well have influenced my quitting. I really didn't want to be a part of the regular business world. But my novel had been rejected by Viking Publishers. I still had to eat, so I got a job with the New York Telephone Company.

I sat at a desk on the third floor of a building on the East Side, looking north over the rooftops of Manhattan. I took applications for new service by telephone and tried to iron out the complaints of old subscribers. One of the imperatives was to keep complaining subscribers from taking their complaints to the Public Service Commission. And after doing all the above, I was supposed to call satisfied subscribers and sell them additional service. I soon learned that a farm boy with a sound moral upbringing could be a misfit.

The company decided that I wasn't cut out for a business office job. But after paying me for a couple of months, management apparently felt that it had an investment in me, so 
I was transferred downtown to the Brooklyn Telephone Directory, as number three of three male supervisors.

A new method of compiling directories was being installed and our job was to get the bugs out of the system. As third man, I had more contact with the field offices. I managed to spot a critical snag in the compiling of names and addresses of new subscribers. I told the second in command. He passed it on to the first supervisor as his own discovery. When our initial work was done, it was decided by the front office that only two supervisors were needed. Being third man, I was let go. But the head supervisor assured me that I could expect "a good recommendation." That made the title of a story I wrote years later. Jack Conroy printed it in The Anvil, one of the early "little" magazines.

My next job was scrounging pictures for the fourteenth edition of the Encyclopaedia Britannica. Warren Cox, son of the American president of the company, was picture editor. Walter B. Pitkin, author of Life Begins at Forty, had named himself American editor on the staff, having convinced management that he could get the new edition out in a year. There was big talk of deadlines which, as a journalist, I could understand, and I busted a gut to meet the first one.

But a faction on the staff felt that deadlines weren't compatible with encyclopedia compilation. Deadlines came and went, and the world didn't end. Pitkin acted as if everything was quite normal. New deadlines were set and missed. Pitkin's contract for one year expired and wasn't renewed. The fourteenth edition of the Encyclopaedia Britannica stumbled along, and no one seemed to worry about when it would get out. I was disillusioned but hung on, saving money for a trip to Europe.

An incident comes to mind from early in my Britannica job. I was supposed to get pictures to illustrate an article on advertising-obviously a first-volume priority. An illustration must was "Sky Writing."

I had made the acquaintance of Warren Basset, one of the editors on a magazine with offices in the Times Square Build- 
ing. He had graduated from Iowa three or four years before I did. Major Maulsby had talked about Warren as one of his most successful students. I dropped in to visit with him from time to time.

Confronted with the advertising deadline for "Sky Writing," I made a point of mentioning the subject to him. He told me to "Try the Sky Writing Corporation of America." Such an obvious source of pix hadn't occurred to me. The corporation was listed in the Manhattan Telephone Directory with an address in the Forty-Second Street area. I went straight there, told the receptionist what I was after, and she got me an $8 \times 10$ black-and-white photograph of the word "RODEO" written above the skyline of Manhattan. If you looked closely or used a magnifying glass you could see a dot at the tail of the " $\mathrm{O}$ " which was the airplane. The Britannica could have it for a credit line reading "Sky Writing Corporation of America."

It was such a spectacular picture that I took it to show Warren. He laughed and advised me: "Take the rest of the day off. Put it on your editor's desk in the morning. Be a little out of breath." I did something like that, and there's a full page of that picture in the fourteenth edition of the encyclopedia.

The sloppy editorial routines disturbed others on the Britannica staff. But it was a job to them. I liked a lot of those guys. One of the departmental editors, Monty Schuyler, knew Howard Scott, the inventor of technocracy. Monty was a disciple. He loved to expound the merits of a society run by engineers over lunch or in a speakeasy getting drunk on weekends.

Monty introduced me to Scott once in a restaurant in Greenwich Village. I had reservations about turning society over to engineers. And Monty didn't give me a very satisfying idea where the writer would fit in a technocracy.

I was still bent on becoming a writer. Ruth Lechlitner and I were living together. I consider her the best woman poet since Emily Dickinson. We were approaching our savings goal for a year in Europe. But there were snags.

In those days a passport cost $\$ 10$, and visas for many European countries cost $\$ 10$. Today $\$ 10$ is almost an insignifi- 
cant amount. In 1928, it meant living ten days in France. If we remained unmarried, each would require a passport and separate visas, but married, both would be on one passport. So we got married.

Ruth was working on the Nation at the time. She lived through the struggle to save Sacco and Vanzetti, and she passed a lot of agonizing along to me. I can still remember sitting on the stoop of a brownstone on West Fourth Street the night they were executed. I didn't feel it as much as Ruth did. She had been living that nightmare at the Nation for weeks.

In 1928, Al Smith ran against Hoover in the presidential election. I was barely aware of the campaign. I wasn't votingremember? We sailed for France on the De Grasse in late August and reached Le Havre in early September. Most French favored Al Smith because he was against prohibition. We could agree on that. A peace pact was signed in Paris that fall (the Pact of Paris or the Kellogg-Briand Pact). Only the history books remember.

In October, we bicycled from Paris to the Riviera. We went over mountains I hadn't realized were there. In one village where we stayed, we were the first Americans the natives had ever met. One of the kids asked "Do you know Leenberg?"

I started a beard as soon as we reached Paris, and by the time we got to Bandol-sur-mer on the Mediterranean it was apparent, but pale and wispy. We found a real estate office where the lady spoke English and inquired about a villa. She took a long time examining our passport, but finally took us to a nice little place across the road from the sea. We paid the six months rent in advance. Then she explained her first hesitation; she thought we were Russians.

During the months we lived in Bandol, I got little writing done. There was no reason to be optimistic about my becoming a writer. I began to feel that perhaps I was like others I had known who said they wanted to write, but after they got married and had sex regularly, they never got around to writing. They took a job, started a family, and the dream of becoming a writer remained only a dream. 
That winter, Bandol saw snow for the first time in years - the palm trees froze. We met wives of British colonial officials in India sent back to winter on the Riviera (a couple because they had proven an embarrassment to their husbands). I remember a French colonial businessman, on a week of R-and-R, after a stint in Southeast Asia. He told me about doing business with the Chinese. He said that with the Chinese all he needed was their word and a handshake. But any business he did with Japanese had to be put in writing.

Americans stopped there for a holiday. A man named Bowles had retired there, after years as public relations man for the Ringling Brothers Circus. The high point was meeting D. $H$. and Frieda Lawrence. He had a very conspicuous beard. He and I passed a number of times when we were out walking. I was conscious of him eyeing me. My own beard couldn't compare with his so I shaved mine off.

There was common ground between Ruth and the Lawrences. She had taught in New Mexico. They had lived in Taos. Ruth finally got up courage to approach Frieda. As soon as they learned that she had lived in New Mexico, they were eager to talk. Ruth invited them to our villa for tea. It was a brief encounter. They were friendly, ordinary people. Lawrence was anxious to get back to Taos. He advised me to stop off in London on our way back to America and see J. Middleton Murray. He was supposed to be helpful to aspiring writers.

In early April that year, we received a letter from our friend Charles Nelson, describing property they had found near Cold Spring-on-Hudson. He and his wife Kay wanted us to join them in buying it. There were two houses and 25 or 26 acres and the price was $\$ 6,000$. We still had more than $\$ 1,000$ of our European trip savings and could have stayed another year. But we decided to take up the Nelson offer and return home. We went by way of London. I called on J. Middleton Murray at his magazine. He sent a sub-editor out to talk to me who offered no encouragement to anyone wanting to write.

We sailed home on the Lancastria in late May. On board, I made the acquaintance of a South African minister, an Afri- 
kaner, coming to America to get support for the white African cause. I wasn't much impressed with him or his cause. But that could have been because he beat me regularly at chess.

Our arrival in New York harbor with full sight of the Statue of Liberty I don't remember as being particularly stirring. There was the immediate matter of getting through customs. But I think I was more excited by the prospects of the land we were going to buy.

That first night we spent with friends in New York City. We took a morning train from Grand Central Station up the Hudson River. That water level ride is spectacular. The Palisades and the highlands across the river rival anything a trip along the Rhine can offer. Across the New York Central tracks from the Cold Spring station, our destination, is a real spring, and nearby a bronze plaque reading, "George Washington drank at this spring."

The "farm" in Putnam County we were buying had been abandoned for years. Fox grass and white birch trees had taken over the fields marked by broken-down stone walls. Charles and Kay had already moved into the main older house on the acreage. A shell of a house on a small plot stood on the drive up to the main property.

When the Nelsons moved up, they had included with their stuff ours we had stored when we went abroad. It was waiting for us in the small cottage on the drive. After a few days of getting acquainted with the place, we made a brief trip to the Middle West to visit families and collect our belongings, left behind, waiting for the day of setting up a permanent home. Then we returned and spent the rest of the summer making the cottage that was to be our part of the deal livable.

September came, and we looked for jobs in the city. Ruth was the first to connect. She started with the $\mathrm{H}$. W. Wilson Company, writing for the Book Review Digest. It took me a month longer to get a job reporting for the Real Estate Record and Builders Guide. We moved back to a one-room apartment on the Upper West Side of Manhattan.

The stock market crash in October seemed hardly more than 
headlines in the papers to us. We knew one person to lose money. The whole financial scene was another world. Ruth settled into her job quickly. She had been writing book reviews for years, digesting reviews was easy. But Mr. Wilson, head of the company, was a modern Scrooge. He hired mostly women because they worked for less money. When one of the help needed a new pencil, she had to take the stub she had to him to prove the need. My job was not one that I could get enthusiastic about. News stories about real estate sales was not what I wanted to write. But I had a young boss and the others on the staff were easy to get along with. There was talk of the market crash but none had been burned by it. Yet my prospects were dim for becoming the writer I wanted to be.

People selling apples on street corners became more conspicuous daily. Winter came on, and the unemployed numbers grew. A rally was planned for Union square. The small but noisy Communist Party may have organized it. The day of the meeting, the roofs of buildings surrounding the square were manned with police and government agents with machine guns aimed at the crowd. It's my recollection that a flamboyant politician named Grover Whalen, an ex-floorwalker at Macys, had something to do with the so-called security. The episode was good for a lot of laughs in the office.

The growing depression didn't bother me much. I was full of plans for the property we were acquiring, for making it into a base for writing. That January, Charles and Kay spent a weekend up at their house, going through their belongings and burning unwanted stuff in an old brick fireplace. The following Monday night the house burned down. Although house and belongings were insured, they lost a lot of personal items.

We had a complicated agreement between ourselves in the purchase of the property. The land was to be divided between us. Charles and Kay were to get the land west of a north-south stone wall. They planned to build their house on this site. But the house they had taken over and were occupying was on the smaller portion which we were taking. We didn't want the old house. Building my own was part of my dream. So the 
agreement between the two couples allowed for the tearing down of the older house and the division of the materials. Now the fire had taken care of that. And the insurance went to the seller of the property.

In our agreement, the cottage on the small lot on the drive, which we were occupying, was to be sold as soon as I got a place built on our portion of the land, and the proceeds divided between the four of us. With the money Ruth and I had left over from our European trip and a small inheritance from my mother, we were able to pay for our portion of the land. We planned that in the spring I would quit my job and start building a cottage on our property now free and clear. And this was where Ruth and I would live and write eventually. And in March of 1930, we had enough money still to buy a Model A Ford pickup, an item indispensable to any building plans.

Our lives seemed to be working out. My boss already knew that I planned to quit on the first of April. Somehow he had got the notion that I might be after his job. He had said to me once, "Don't ever think you can get my job away from me." The idea was ridiculous to me. But apparently he had gotten his present job by undercutting his predecessor, and he had started out in my job. So I told him my plans to keep him from harassing me.

When the time came for me to quit, it shocked the office force. With the country getting daily deeper into the depression, it seemed completely insane. To many people the threat of communism loomed bigger every minute. One of the guys in the advertising department asked me what I intended to do, "retiring to the country." Facetiously, I said, "I'm going to pour concrete slabs for Russian siege guns."

I remembered reading somewhere that in World War I, the Germans had prepared for an attack on Antwerp by having infiltrators pour concrete foundations for temporary structures around the city. When war came and the Kaiser's armies invaded Belgium, all that had to be done was burn the structures and place siege guns on the slabs. I didn't explain that to Bill, the guy in advertising. It seemed to me a great joke to make believe that I was going to pour slabs for Red siege 
guns attacking New York City. It didn't occur to me that anyone would possibly take me seriously.

That summer I got only the shell of a cottage built. In the fall, I returned to the city and got a job with the Crowell Company on an encyclopedia they were compiling. The depression didn't seem so bad. Oh yes, there were lots of people out of work, but I got my job easily enough. Although the previous winter I'd been paid $\$ 50$ a week, this fall I was started at $\$ 30$.

My boss of the previous winter and I were still on friendly terms, largely because I had proven no threat to his job. Occasionally, I dropped in to see him. On one of our visits he confided to me that I had given Bill, in advertising, a bad time when I quit last spring.

"Bill came to me," he said, "very worried. He didn't know what to do. Should he tell the FBI what you had said about building gun emplacements for the Russian siege guns?" He had assured Bill that I was only spoofing. We had a good laugh over that.

Again on April 1, 1931, I quit my encyclopedia job and returned to Putnam County. By this time, our friends the Nelsons had a well drilled on their land. On two weekends, they, a friend Charlton Laird, and I had built a one-room cabin for them to live in until they could get their big house started.

This spring I hoped to finish off the cottage I had put up the previous summer. The past winter we had a well drilled on our property and by the end of the academic year we could move into our home on our land. That meant that the cottage on the drive would be vacant.

Our friend Laird, who had helped in the building of the Nelson cabin, had been working on his doctorate at Columbia University. He and his wife, Floy, both friends from lowa days, took over the vacant cottage. He only needed to go down to the city occasionally to discuss his work with his advisers or get more research material.

The past summer, Ruth had commuted to her job at the Book Review Digest. This year, she worked out an arrangement with her boss, Mr. Wilson, to do her writing up in the country and 
only report to the office once every couple of weeks. She had impressed Mr. Wilson with what we were doing. He felt that young people should be self-sufficient, raise their own vegetables, raise chickens. If every couple did that, there would be no need for soup lines and people selling apples on street corners. We were showing the right American stuff.

That spring we planted gardens. We raised chickens. We had a milk goat. The depression seemed like something far away. Of the three couples, Charles Nelson was the only one to commute daily. He had a good job with an art auction firm. Charlton and Ruth went in when necessary; he for research or counseling, she to turn in copy to the Book Review Digest and get more material to work on.

We had a regular routine. Charlton studied in the mornings. Ruth did her digest work for the Wilson Company, reviewing for the New York Herald-Tribune Books and writing poetry. I put in every morning between 8:00 and 11:30 at the typewriter. Floy Laird and Kay Nelson had their own work to do.

In the afternoons, Charlton and I laid up the stone walls for a building on an abandoned cement slab near the Nelson's well and cabin. This structure was to give Charles and Kay more living space now, and would become a garage when they got their big house built. Charles paid us for this. It provided eating money.

While we mixed concrete and laid up stones, Charlton and I reminisced and discussed news happenings. A gangster in Harlem had opened up with a machine gun on a crowded street, people were killed, even a youngster. We talked about living in an age of gangsters and speakeasies: we were living in a "machine gun culture." The idea for a satirical article grew out of our banter-"Machine Gun Culture." Charlton, Floy, Ruth, and I each wrote a version of the idea.

The four versions became one and it was submitted to Vanity Fair over the byline of Corey Laird. But the magazine had a regular satirist named Corey Ford. Corey Laird was asked to stop at the office, and Charlton did the next time he was in the city. He talked with Clair Booth Brokaw, later Clair Booth Luce, 
who explained the situation. Charlton told her how the name had been arrived at and offered to change it. The article was accepted, appeared over Charlton's name, and we got $\$ 100$. My share of $\$ 25$ was the first money I ever got from free-lancing. The circumstances and the amount were hardly such to encourage me.

By this time, we were in an election year. I paid little attention to the Roosevelt-Hoover campaign; I had no intention of voting. Neither Ruth nor I registered. However, I was glad FDR won. After all, my political heritage was Democrat, even though my first vote had been cast for a third-party candidate.

That fall, I stuck to my typewriter from 8:00 until after 1:00. I tried to find solid ground for my writing. Roosevelt's inauguration followed by the Bank Holiday stirred me up. We didn't have much money in the bank, but breadlines, streetcorner apple sellers, news of farm foreclosures and drought in the Middle West finally began to soak in.

Social consciousness became a writer's goal. It was plugged by the John Reed Club, a Communist-run organization. I didn't pay too much attention to that either. But I had turned to writing about life I knew: the farm where I grew up. At that time "farm fiction" had been blighted by the Middle Western farm fiction writers who preceded me. The label farm fiction could stop any story dead in a magazine slushpile.

Southern farm fiction was different. Erskine Caldwell's Tobacco Road was a best-seller. Its popularity seemed to stem from the raunchy life in tobacco country. I said to myself, there's nothing that happens in Caldwell's book that hasn't happened where I grew up in Iowa. So I wrote a series of sketches tied together by the braying of a jackass. Each incident happened in an area reached by the sound of Little Ben's bray, roughly an area three miles square. I called it "Land o' Love.

"Little" magazines had begun to sprout. One called 1933: A Year Magazine was started by Jack and Ada Stoll in Philadelphia. I submitted my story, and it was accepted but Jack changed the title to "Mid-American Sketches." My original title had turned Jack off, and he dumped the manuscript in Ada's 
lap. Later she told me that after she'd read it, she told Jack, "You'd better read this."

That was my real beginning in print. After a few more acceptances, a good friend, Buel Beems, a lawyer in the city, a former Iowan, and a part-time writer himself, urged me to make a trip to the Middle West. I went in September 1935, an in-between drought year. But the dust bowl effects of the previous year were evident. On the homeplace, still run by Rob and family, the absence of familiar trees were drought scars. My brother told me that the previous year he had put up Russian thistles for winter forage. "Better than a snowbank for the stock," he said.

I learned about "Sears Roebuck" farm sales: at a foreclosure sale, neighbors offered $\$ 1$ and threatened violence to anyone who offered more. I hitchhiked out to South Dakota to visit my sister Elizabeth and went through Le Mars, Iowa, where a mob of farmers had threatened to "string up" a judge ordering a sale. Rob had told me that kids I'd grown up with had been in that mob. The National Guard was called out and arrested many of them, so many they had to be kept in a barbwire enclosure. Rob said, if anyone asked where Cliff or Joe were, they were told, "He got kicked by a mule" or "He's got the flu."

I found my sister on relief in Pierre. She had gone to South Dakota in 1910, homesteaded, taught country school, and had acquired a half-section of land. She was the epitome of feminism, not the strident kind, just determined to make it on her own. She signed her letters home "Bachelor Bess." Her ranch or claim was rented to a neighbor but wasn't producing anything. Dust from the previous year had drifted to the tops of fence posts in places. My sister hadn't mentioned her situation. We were a stiff-upper-lip family, and relief was charity, and accepting charity was to be avoided. I looked for an idea that might help Bess.

Our Aunt Hattie in Atlantic, one of three old maid aunts, baked a ginger cookie to sell. She baked sugar cookies and bread but the ginger cookies were what she was famous for. Her sisters were seamstresses, and a bachelor brother ran a 
truck farm at the edge of town. I especially remembered those cookies. From time to time she'd send some out to the farm. I talked her into giving me her recipe. My idea was to take it to Bess and maybe she could bake and sell the cookies and get herself off the relief rolls.

My aunt told me there really wasn't any secret about the recipe. Originally she had been able to get ten gallons of very black New Orleans blackstrap molasses, which she kept in the cellar and used in her baking. Out in South Dakota, the only blackstrap molasses was the ordinary kind anybody could buy. My sister baked a batch but they were just ordinary ginger cookies with frosting, the kind any housewife could make. That ended that free enterprise venture. Bess stayed on welfare until the coming of WW II picked up the economy.

While I was in South Dakota, Bess showed me a newspaper clipping she had kept for years. It was about my father as treasurer of Shelby County, Iowa. When the state auditor examined the books of the 99 county treasurers, he reported that the books kept "by Treasurer E. O. Corey of Shelby County were the only ones that balanced."

She was very proud of the clipping. But I can't remember expressing surprise or pleasure. I hadn't known that he'd been a county treasurer. In my growing up years, no one had ever mentioned it to me. Here I was 32 years old and hadn't known that my father had been treasurer of the county where I was born. Despite my father's death before I was two years old, one would have thought that somewhere during my growing up, my mother, or siblings, or a neighbor would have mentioned my father in politics. The fact didn't sink in then. It was at least three decades later before the fact surfaced again.

Of course, a lot happened on that trip to obscure it. In spite of our sort of isolation in Putnam County, New York, we kept up on happenings. The rise of Huey Long and his slogan "Every Man a King" didn't mean much in the East. But in Iowa, the farmers were interested in him. In South Dakota, I got the feeling that a lot of people thought of him as a leader who could lick the depression. I had always considered him a 
fascist type. Then, while I was in Pierre, he was assassinated. The people I talked to were shaken and hurt-it was a great loss to a lot of them.

But there were other potential leaders in the early thirties. Howard Scott's technocracy was given some recognition when FDR invited him down to Washington to discuss his ideas. The conservatives came up with "the man on the white horse," retired Marine General Smedley D. Butler. But he proved too radical for them.

A friend in California sent me a copy of a booklet by Upton Sinclair entitled I, Governor of California, and How I Ended Poverty. He ran for governor, and it took every viable Republican and right-wing Democrat to defeat him. Later he wrote another booklet called I, Candidate for Governor: and How I Got Licked. Then along came Doctor Townsend's plan for the senior citizen. . . .

About this time one of my stories about the redwood lumber mill was accepted by a "little" magazine published in California. The story actually got read in Scotia and someone there sent me a subscription to The American Guardian, a weekly newspaper edited and published by Oscar Ameringer. It was a great little sheet pushing left-wing ideas and cutting down the reactionaries and right wingers. But above everything the paper had a great sense of humor. I could never swallow the deadly seriousness of Marxist philosophy.

Also on the Middle Western trip, I stopped to visit friends in Des Moines. I was told about Pete Jantz. He was a promising lawyer who had become a Robert Taft Republican. I dropped in on an organizational meeting he was holding in one of the hotels. I asked him how his mother felt about him becoming a Republican. He admitted that she wasn't too happy about it.

I got good solid feelings about people on the trip. When I returned to Putnam County, I took up my routine of writing in the morning and working outdoors in the afternoon. About this time, I sold a story to Scribner's Magazine-my first sale to a quality publication. The title was "There's Always an Accident." On the road from our place to Cold Spring was an 
intersection. Local folks who couldn't afford the usual entertainment came out Sunday afternoons and sat on high ground overlooking this intersection. Sooner or later there was an accident, a fender-bender or worse. It took a traffic light several years later to spoil the fun.

My story indicated a certain growth in social consciousness. But basically I had developed no consistent focus. From reading and talking to people, certain ideas were taking shape. I have always considered the human brain the original computer, and unbeknownst to me a lot of notions were getting together.

In the election of 1936, I had a gut feeling that FDR would win. Predictions that Landon would win, especially the Literary Digest poll which gave Landon a landslide victory, didn't alter my feelings. I had regained enough political awareness to consider voting again.

So Ruth and I registered. At the time, I felt that jury duty would be a good experience. I asked a local politician how one got called for jury duty. He told me "register as a Republican." He was a Republican. So we did. It wasn't until 1946 that I was finally called for jury duty - the grand jury. Later, that politician whose advice we took was made a judge. Once I asked him why women weren't called for jury (Ruth was present at the time), and he replied, "Oh, women could probably function all right on a jury."

That fall I voted for Earl Browder, not that I expected or hoped he would win. My rationale at the time: the stronger the left-wing vote the more liberal would be the party that won. At that time, no one had asked me to join the Communist Party. Of course, living where we did would limit any party work I could do. Anyhow, I felt that I couldn't take party discipline. First off, I didn't want anything to interfere with my own self-discipline.

Basically, I oppose our so-called two-party system. We have a one-party system, just like any totalitarian country, only ours is the capitalist party which is split into Democrats and Republicans. That year the League of American Writers was formed. 
Almost immediately it split into two factions, pro-Stalin and pro-Trotsky. To be one or the other was to me the same as being a pro-Democrat or a pro-Republican capitalist. An English envoy to Russia in the early 1920s said that "Trotsky was willing to die for the revolution if he had a large enough audience."

In the 1930s, anyone who had a kind word for the Soviet Union, if he/she wasn't a Communist, was called a fellow traveler. A communist could use the term as a compliment; a capitalist used it as a smear. I got called fellow traveler by both sides, and I always replied: "I'm on the train ahead." That was admittedly a flip answer, but it always stopped the name-caller cold.

Then came the Hitler-Stalin Pact in 1939. Left wingers and liberals were mightily disturbed. Trendy Communists dropped the party, like capitalists jumping out of windows in 1929. The pact didn't bother me. Time magazine as early as January or February of that year had written that England and France had hoped that the Munich Pact, signed by Chamberlain, would get Germany and Russia into a war, and they could stand aloof while the two destroyed each other. Perhaps they could make a bit of profit out of selling to both adversaries.

I was aware that Hitler and Stalin had made a cold-blooded deal. But so had Chamberlain and Hitler in their "peace in our time." While American left wingers squirmed and Communist Party members had second thoughts, I, a non-Communist, explained the situation to myself and anyone else and felt comfortable if not happy with it. Unhappy because, although the West had climbed in bed with Hitler at Munich and that was all right, it wasn't considered all right if the East did the same thing for basically the same reason.

Why I picked up that statement from Time and let it maintain my equilibrium while others were being upset, I am at a loss to explain. Perhaps it was the result of being alone a lot in the country. I had plenty of time to think. And thinking can be a dangerous thing.

The Hitler-Stalin Pact did Browder in. Nevertheless, I was so 
sure FDR would be reelected in 1940 that I voted for Norman Thomas. That fall I'd been back to the Middle West again, and quite by accident, I rode the same train as Thomas between Cedar Rapids and Cedar Falls. I didn't meet him and he continued on, but I had a lawyer to interview in Cedar Falls, a lawyer who had defended farmers accused of trying to lynch the judge in Le Mars years earlier. My excuse for voting Socialist in 1940 was the same as my voting Communist in 1936.

And I can't explain why, after the Nazis attacked the Soviets, in 1941, and our General Marshall predicted that the Russians would collapse in six weeks, that I couldn't accept such a negative conclusion either. Perhaps it was another gut feeling that the Russians could not collapse before the Nazi onslaught, or maybe it was that I had recently reread Tolstoy's War and Peace and felt that if the Russians could defeat Napoleon, they could defeat Hitler. But more to the point was my feeling that if the Soviets collapsed as Marshall predicted, the Western world, all of us, were doomed to end up goose-stepping. And for 1,000 years as Hitler had predicted.

Perhaps General Marshall made his prediction to arouse the American people to the necessity of supporting the Soviets. I very much doubt that. My feeling then and now is that he expressed American capitalist leadership. Help for Russia only came later when the Nazis were stopped at the "second" Battle of Smolensk. Then the West had a new fear. What if the Russians defeated Hitler and we had no part in it? It would be better for us to send help, if only token help.

It wasn't until 1944 that I finally voted for FDR. I was afraid he might not be reelected. It would be a disaster, I felt, to turn the finish of World War II over to Dewey. And, if that happened, I didn't want to feel that I hadn't done the little that anyone can do, give up my vote for the regime.

By that time, I suppose I was a thorough-going liberal. I had registered as an independent. I have never even registered as a Communist; I have known others who have, who weren't really Marxists. To me, there is as much lacking in MarxistLeninist communism as there is lacking in capitalism. A 
different lacking, perhaps, but equally debilitating to human beings. However, never having been a card-carrying Communist can place a liberal in a predicament. For instance, when a liberal's ideas of life get that person accused of being a Communist, how can he/she prove otherwise?

During the 1930s many joined the CP because they were emotionally swayed. When the McCarthy witch hunts made it dangerous to be a party member they could tear up their cards, beat their chests in a fake show of humiliation, plead gullibility, foolishness, youth, and say they had learned their lesson. Such a penitent prodigal was welcomed back to the establishment. But woe to the liberal who never joined the party. Should his/her ideas become suspect, how could they prove their innocence?

It is not enough to say, "I was never a Communist!" There is no way to prove it. There is no defense against such an accusation. The suspicion can dog that person for years. Such a person was/is not black-listed. Such a person is gray-listed. During the McCarthy era, my agent advised me to channel my writing into the field of "how-to" and "do-it-yourself" because the witch hunters weren't looking at that field.

After almost twenty years of fighting New York winters, we came to California in 1947. Later there were anti-Communist riots in Peekskill, fourteen miles from where we had lived. At the time, I wondered if we would have been affected had we still been living there.

From out in sunny California, I followed the course of the Alger Hiss trial and the ridiculous histrionics of the Chambers Pumpkin Patch incident. I followed with considerable dismay the events building toward that human sacrifice to the gods of capitalism in the execution of Ethel and Julius Rosenberg. It all brought back the memory of sitting on the stoop of a brownstone in Greenwich Village twenty-five years earlier waiting for the human sacrifice of Sacco and Vanzetti.

In spite of the obvious heavy fist of repression, my ideas did not change. I believed the fighting in Korea was a war and not a police action. Containment is/was not the answer to commu- 
nism. I opposed the fighting in Viet Nam. To the argument that "they" had to be stopped in Nam or we'd have to stop "them" on Market Street, I replied that by the time they get to Market Street they will all be Republicans. I have a weakness for being flip.

I felt that opposition to Castro in Cuba was a mistake, and the Bay of Pigs adventure was a mistake. Kennedy, I felt, handled the Missile Crisis correctly. That was the scenario the media fed the public. What really happened was that Kennedy told Khrushchev that the United States had no intention of invading Cuba and Khrushchev took the missiles out. It was as simple as that.

No matter how true or false such a conclusion might be, it is dangerous to voice it in our "free" United States. Long ago I learned that almost anything can be said about our capitalist system as long as it isn't true. Marxists can prate about the proletariat with impunity. The U.S. doesn't have a proletariat. Ask even the most destitute of our citizenry if they consider themselves members of a proletariat and they will tell you defiantly that they are middle-class folk down on their uppers.

As some wise person has said, the trouble with democracy in this country is that the poor think they have it and the rich are afraid they might get it. Only when certain leaders feel that the people must be scared into a proper respect for the free enterprise system is the bogy of Marxism/communism raised. It's not that these leaders are afraid that the American public might be induced to embrace communism, but they are fearful that the American people might feel that some of the "rights" granted under communism such as the right to a job, home, education, medical care, and so forth, would be a good thing to have themselves.

I never really wondered about my philosophical-political views until 1973 or 1974 . At that time, my youngest nephew, Gilbert Corey, was laid off from his tool-designing job and decided to amuse himself shaking the family tree. He uncovered the fact that my father had been a supervisor in Shelby County, Iowa. In 1935 I'd learned that my father had been a 
county treasurer, but it hadn't soaked into my consciousness. Then, when I turned seventy, I learned that he was also a supervisor-my father had been a politician.

Why, in all the intervening years, hadn't I been told of it? Why hadn't my mother said something, or an aunt or uncle talked to me about it? As a kid, why hadn't other kids mentioned something they had picked up from their parents' talk that related to my father's political life?

I remember being told about a trip my folks had made down to Arkansas the September after I was a year old. They had taken me along. Later I learned that a family move to that state had been considered. But no one told me why.

When I was old enough to remember such details, my brother Chall (Challenge), five and a half years older than me, hinted at a family skeleton. It seems that my father's younger brother had gotten into some sort of money trouble, had forged a check or something. I specifically remember Chall's conspiratorial attitude. I was admonished "not to mention it to a soul."

I remember it as a feeling of family shame. An uncle of mine was a "wrong-doer." What was "right" and what was "wrong" were heavy subjects in my family. It might have been that as a kid my uncle, whom I had never met, and his wrong-doing was more than my small brain could handle, so I hid it away in my mind.

An awareness of the meaning of "bad" seems to have come to me early. I recall a winter afternoon before I was three years old. A neighbor had called bringing her not-quite-a-year-old baby. In those days babies were put in dresses no matter the sex. Clifford wore a red flannel dress. We were playing in our sitting room with blocks, and he had knocked over something I had built. I struck him and he cried.

I can still see myself burying my face in the thin pad that covered a box behind the wood stove. That box was papered with green wallpaper with a pink flower design. It was used to store blankets and such in our cramped farm home. I don't remember being scolded for my behavior, but I was attempting to hide from a shameful deed. 
In my growing up later, my uncle's "shameful" deed was never spelled out to me. I came to realize that the sudden silence of my elders when I appeared could have had something to do with it. But I was afraid to say anything, afraid to really know more. I did gather from words dropped now and then that the whole family had banded together to bail this uncle out of his trouble. I don't know if they were ever repaid. As a kid, that didn't overly bother me.

Then, fifty or more years later, it suddenly dawned on me that to anyone in politics in the 1890 s a brother in trouble with the law meant disaster to a political career. It must have been a crushing blow to my father who had been elected to two public offices.

So he had considered moving his family to another state, hoping this onus would not follow him. I now realize how serious such a consideration was. But the Iowa winter intervened. My father contracted pneumonia. That was long before the days of sulfa drugs. In those days, pneumonia was a killer. To a man in his late forties, with his career ruined, death might, in a sense, have been welcomed.

But left behind was Margaret Morgan Brown Corey, a widow with seven children, one just a toddler, and 160 acres of land still not paid for. My mother finding herself in, if not a hostile environment, at least one with whisperings behind her back, made up her mind to stay and run the farm. She had three sons big enough to do the necessary work. But what she chose to do meant in her words "a hard row to hoe."

When I was eight or nine, she had had a chance to remarry, but rejected the offer. That too was a fact that I didn't know until reading my sister Bess' letters years later. I remember Mother in those days, wearing a black skirt and a white shirtwaist. She wore that outfit when she drove our horse and buggy to town to shop. She wore it when she went to church. That one outfit seems to have been the only dress-up clothing she had until she moved to Atlantic when I was fourteen.

That sort of awareness of our penury might not have been so hard to live with had I known that my father had been a 
politician when he lived. We had been a political family. I might have felt that I came by liberal ideas honestly from a politician who as a county treasurer had made the county books balance.

I wish now that I hadn't been so intimidated by my elders, that I had asked about the family skeleton. I wish I had insisted on knowing what had happened in the family those few years before I was born. Of course, if I had, maybe I would have become a conservative, a reactionary, even a Republican. After all, two of my older brothers became Republicans. 